\title{
A Case of Intralabyrinthine Schwannoma and Literature Review of the Cases Reported Previously in Korea
}

\author{
Hyunjong Jeon $\mathbb{D}^{\mathbb{D}}$, Heesung Chae $\mathbb{D}^{\mathbb{D}}$, Haneul Lee ${ }^{\mathbb{D}}$, and Young Joon Seo $\mathbb{1}$ \\ Department of Otorhinolaryngology-Head and Neck Surgery, and Research Institute of Hearing Enhancement, \\ Yonsei University Wonju Severance Christian Hospital, Wonju, Korea \\ 미로내 신경초종 1 예와 이전 국내에서 보고된 미로내 신경초종 증례의 문헌 고찰 \\ 전현종 · 채희성 · 이하늘 · 서영준 \\ 연세대학교 원주의과대학 이비인후과학교실 및 청각재활연구소
}

\author{
Received August 5, 2019 \\ Revised November 21, 2019 \\ Accepted November 26, 2019 \\ Address for correspondence \\ Young Joon Seo, MD, PhD \\ Department of Otorhinolaryngology- \\ Head and Neck Surgery, \\ Yonsei University \\ Wonju College of Medicine, \\ 20 Ilsan-ro, Wonju 26426, Korea \\ Tel $+82-33-733-0640$ \\ Fax $+82-33-741-0644$ \\ E-mail okas2000@hanmail.net
}

\begin{abstract}
Vestibular schwannoma is a rare tumor that develops in the nerves responsible for vestibular function and hearing. It usually affects middle-aged people, and is diagnosed by hearing and imaging tests. In the majority of cases, it occurs in the retro-cochlear space and very rarely in the labyrinth. Several vestibular schwannoma localized in the labyrinth have been reported worldwide. Since then 5 cases have been reported. With advances in the imaging study, the diagnosis of intralabyrinthine schwannomas have increased. Our report describes the characteristics and treatments of intralabyrinthine schwannomas reported in Korea, including five previously reported cases and the case experienced by authors.
\end{abstract}

Korean J Otorhinolaryngol-Head Neck Surg 2020;63(6):270-5

Key Words Intralabyrinthine vestibular schwannoma $\cdot$ Labyrinthinectomy ·

Vestibular schwannoma.

\section{서 론}

전정신경초종(vestibular schwannoma)은 전정기능과 청 력을 담당하는 신경에서 자라나는 종양으로 발병률은 100만 명 당 20 80명 정도로 흔하지 않은 종양이다.,2) 악성 신경초 종(malignant schwannoma)은 유병률이 100만명 당 1명 정 도로 추정되는 굉장히 드문 질환으로 대다수의 신경초종 (schwannoma)은 악성화를 일으키지 않는 양성 종양이다. ${ }^{3)}$ 또한 현재까지 보고된 바에 의하면 종양의 성장 속도는 0.62 4 mm/yr 정도로 매우 천천히 자라나는 종양으로 내이 신경의 신경초종(sheath of the vestibulocochlear nerve)을 형성하는 슈반세포(Schwann cell)에서 기원한다. ${ }^{45)}$ 대다수의 경우, 내이신경의 위쪽분지(vestibular branch)가 신경초종으

This is an Open Access article distributed under the terms of the Creative Commons Attribution Non-Commercial License (https://creativecommons.org/licenses/by-nc/4.0) which permits unrestricted non-commercial use, distribution, and reproduction in any medium, provided the original work is properly cited.
로 발전하는 경우가 많고, 대부분 종양은 내이도 뒤쪽에서 발 생한다. 아랫쪽분지(cochlear branch)에서 신경초종이 기원 하는 경우는 거의 없다. 또한 1966년부터 축적된 통계에 의하 면 미로 내에서 발생하는 신경초종은 100 만명 당 2.6 명으로 매우 드물게 발생한다. 고전적으로 전정에서 기원한 신경초종 은 50대에 진단되는 경우가 가장 흔하며 여성에서 더 흔히 보 고된다. ${ }^{6}$ 신경초종은 시간이 지남에 따라 여러 임상 양상으로 나타나는데 보고된 바에 의하면 점진적인 청력저하(85.8\%), 안면마비(48.9\%), 이명(40.1\%), 현훈(15.9\%) 등의 증상을 유 발하며 이는 대다수가 청신경 기능 장애에 의해 발생한다.) 신경초종의 경우 일반적으로 경과관찰, 방사선수술(radiosurgery), 그리고 외과적 절제라는 치료 선택지가 있으며 $2 \mathrm{~cm}$ 미만으로 크기가 크지 않고 증상이 없는 경우에는 경과관찰 을 하게 된다. ${ }^{8)}$ 1972년 Karlan 등에에 의해 미로내 국한된 신 경초종이 처음 보고되었으며, 국내에선 2006년 Choi 등(1)에 의해 첫 보고 이후 현재까지 5 예가 보고되었다. 
저자는 현훈을 주소로 내원한 55세 여자 환자에서 미로내 신경초종이 자란 증례 1 예를 경험하였기에 이전에 국내 보고 된 증례들과 함께 고찰하려고 한다.

\section{증 례}

55세 여자 환자로 3 년 전부터 우측 귀의 지속적인 이명을 주소로 내원하였다. 동반하는 증상으로는 3년 전부터 급격 히 악화된 우측 청력 저하와 5 개월 전 시작된 현훈을 호소하 였다. 환자는 증상 발생 당시 1 차 의료기관에서 청력검사는 시행 받았으나 영상 검사 등의 추가적인 검사는 시행받지 않 았으며 가족력은 없었다.

처음 내원 당시 시행한 이학적 검사 상 양쪽 고막에서는 발 적이나 천공 등의 이상소견은 관찰되지 않았으며 당일 시행 한 순음검사(pure tone audiometry)에서는 4분법 상 우측 $81 \mathrm{~dB}$, 좌측 $12 \mathrm{~dB}$ 소견을 보였고 어음검사(speech audiometry)에서는 우측 어음명료도 $0 \%$ 의 소견과 좌측은 어음명료 도 $100 \%$ 의 소견을 보였다(Fig. 1). 고막 임피던스 검사(impedence audiometry)에서 양쪽 타입 A 소견이었다.

갑작스런 청력 저하에 대해 청신경종 감별을 위해 측두골 자기공명영상(temporal MRI contrast)을 시행하였으며 우측 반규관 및 전정 내에 $\mathrm{T} 1$ 강조영상에서 고신호강도와 조영증 강(siganl enhancement)되며 T2 강조영상에서는 저신호강도 를 보이는 종괴가 관찰되었으며 시행한 측두골 전산화단층촬 영(temporal bone CT)에서는 우측 반규관이 $3.40 \mathrm{~mm}$ 로 좌 측 $3.16 \mathrm{~mm}$ 에 비해 약간 확장 된 소견을 보였으며, 이 외에는 중이염 등의 이상 소견은 관찰되지 않았다(Fig. 2).

전기안진검사(electronystagmography)를 시행하였으며, 온 도안진검사에서 우측 반규관은 $100 \%$ 마비 소견을 보였고 자 발안진(spontaneous nystagmus)은 나타나지 않았다(Fig. 3). 빙수안진검사(ice water test)는 시행하지 않았으나 환자가 5개 월 전부터 서서히 악화되는 현훈을 호소하는 것으로 보아 아 직 잔존 전정 기능이 있을 것으로 생각하였다. 비디오 두부충 동검사(Video head-Impulse-Test)에서는 우측으로 시행하 였을 때 시선 재고정 단속운동(catch-up saccade)을 보였다. 주관적 시수직/시수평 검사(subjective visual vertical/horizontal test)에서는 특이 소견을 보이지 않았다.

본 환자의 경우 온도안진검사에서 우측 반규관 마비 소견 을 보이고 우측 청력 역치가 $81 \mathrm{~dB}$ 로 사회적응 청력(serviceable hearing) 이상을 보이는 상태로 정기적인 추적관찰을 권 유하였으나, 환자는 일상 생활에 어려움을 느낄 정도의 현훈 을 지속적으로 호소하고 있었고 종괴로 인한 불안감과 추후
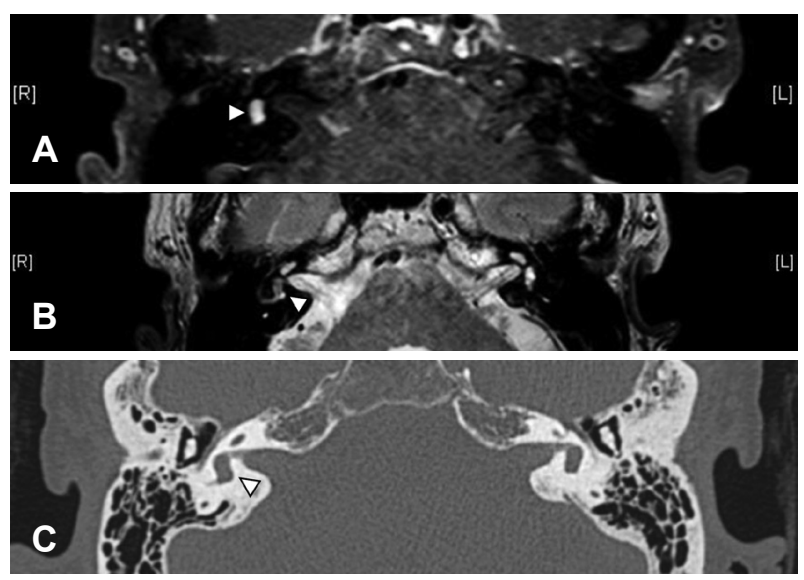

Fig. 2. Preoperative MRI temporal contrast. A: Hyperintense masslike lesion in Rt. semicircular canal (MRI T1 Spectral Presaturation with Inversion Recovery Transverse Gadolinium). B: Hypointense mass-like lesion in Rt. semicircular canal (MRI T2 Transverse). C: Preoperative CT temporal bone. Rt. semicircular canal dilatation was seen, compared to Lt. semicircular canal.
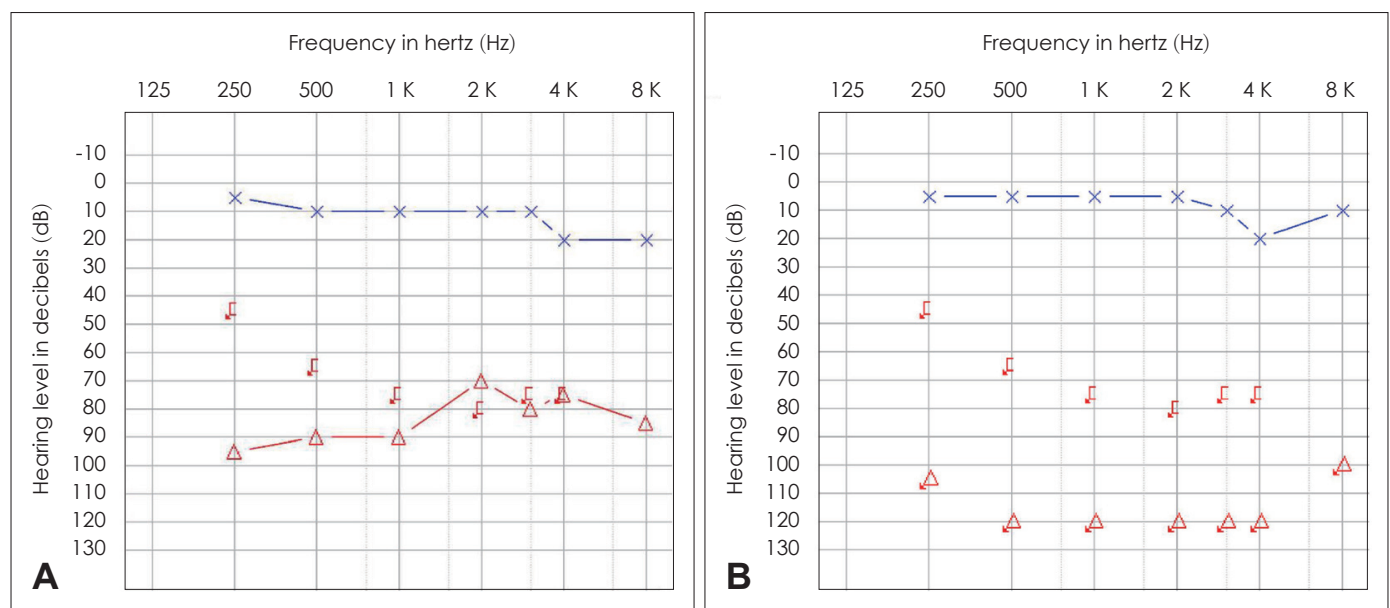

Fig. 1. Preoperative and postoperative pure tone audiometry. A: Pure tone audiometry before surgery. B: Pure tone audiometry after surgery. 
안면마비 발생 가능성으로 인해 적극적인 제거를 원하여 최 소 침습적인 수술을 선택하였다. 반규관 마비 소견을 보였으 나 다른 전정 자극을 통한 어지러움이 있을 것으로 판단하 여 미로절제술을 통한 종양 절제술을 시행하면 현훈이 호전 될 가능성이 있다고 판단하여 수술을 계획하였다. 수술은 전 신 마취하에 진행하였으며 경유양동 접근을 통한 미로절제 술(labyrinthectomy via transmastoid approach)을 하여 종 괴의 감축을 목적으로 하였다. 수술 중 전반규관, 수평반규 관, 후반규관을 모두 개방하였고 전반규관과 수평반규관 내 에서 종괴가 발견되어 병변을 제거하였으며(Fig. 4) 개방된 공 간으로 확인되는 종괴는 보이지 않았고 제거한 종괴의 경계가
명확하여 전정을 개방하지 않았다. 이후 뇌척수액의 유출이 없는 것을 확인한 후 경고제(bone wax)와 주변 근육을 이용 해 종괴를 제거한 부위를 보완한 후 수술을 종료하였다. 떼 어낸 종괴는 $\mathrm{H} \& \mathrm{E}$ 염색과 S-100 염색을 시행하였다(Fig. 5). Ki-67 검사에서 tumor cell은 $1.7 \%$ 의 비율을 보였고 S-100 에서도 양성 소견을 보였다.

수술 후 환자의 현훈은 호전되었고 현재 수술 후 6 개월 째 정기적으로 외래 추적관찰 중이다. 수술 후 1 개월 뒤 시행한 측두골 자기공명영상 촬영(Fig. 6)에서는 잔존하는 종괴나 국 소 재발 소견은 보이지 않았다. 수술 후 6개월에 시행한 순음 검사에서는 우측 전농(deaf) 소견을 보였다.

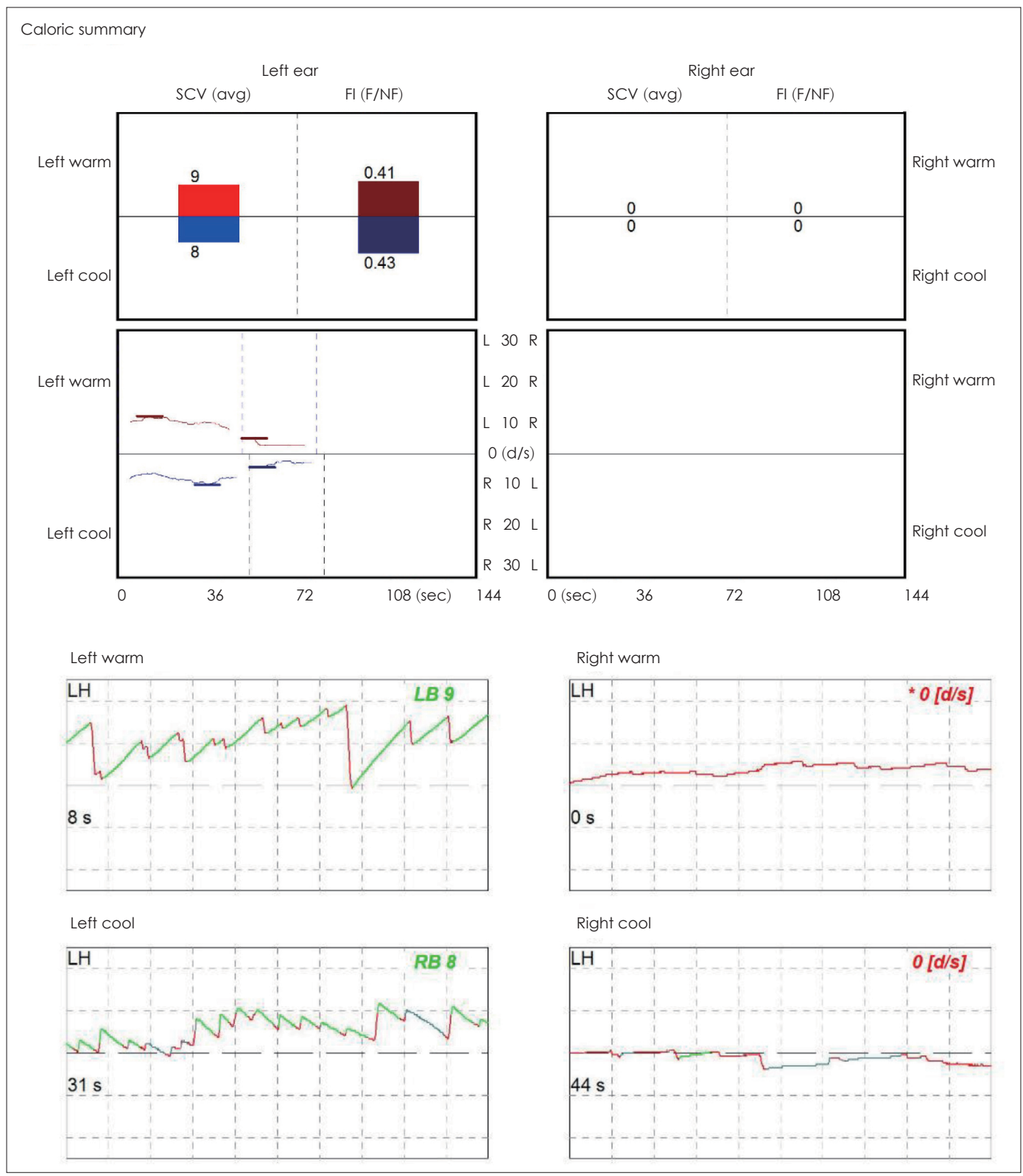

Fig. 3. Findings of Vestibular function test. Bithermal caloric test shows $100 \%$ canal paresis on Rt side. 

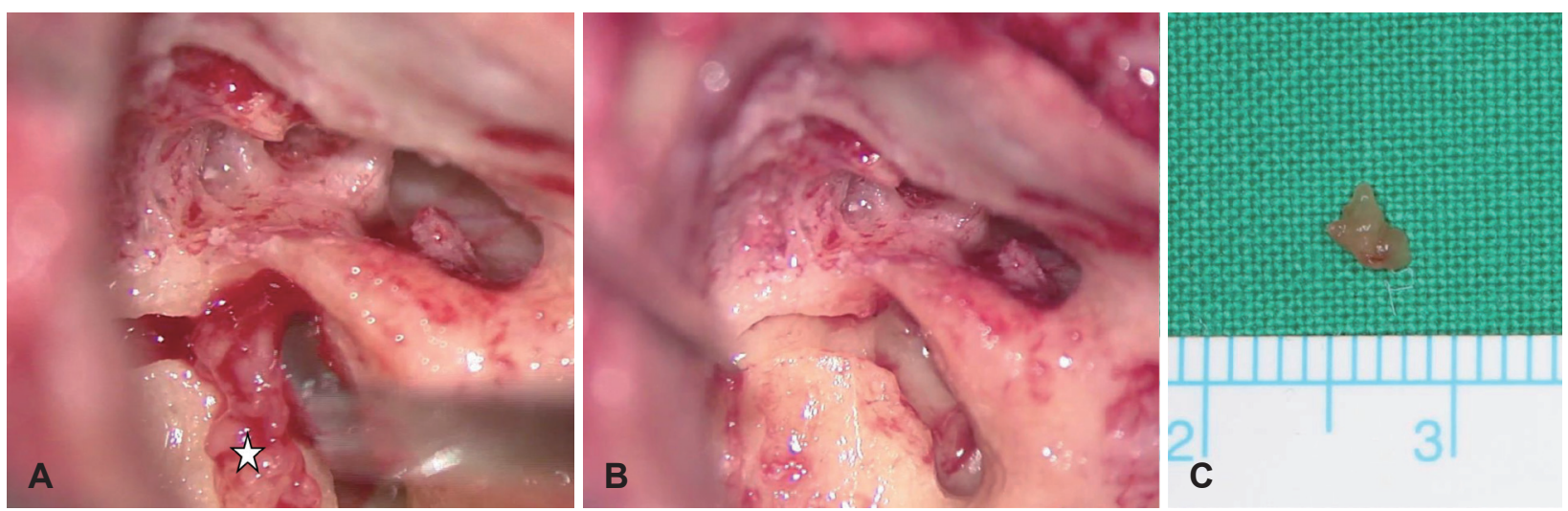

Fig. 4. Surgical images. A: Star mark shows Schwannoma in Lateral semicircualr canal, before surgical resection. B: Schwannoma was removed from Anterior and Lateral semicircular canal. C: Vestibular schwannoma sized $3 \times 3 \mathrm{~mm}$ and $4 \times 6 \mathrm{~mm}$.
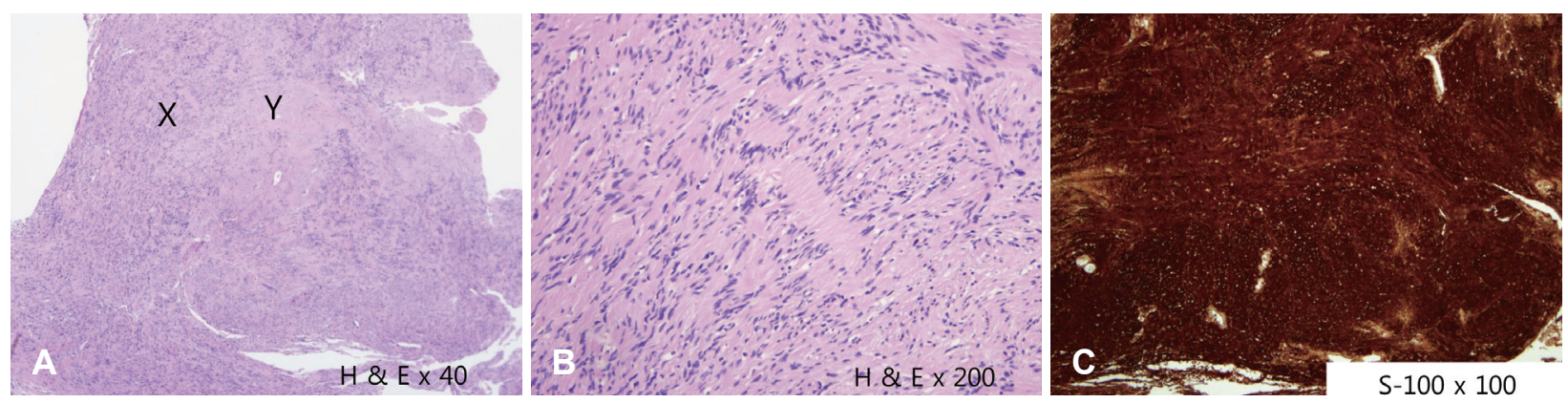

Fig. 5. Histopathologic images of tumor. A: Schwannoma are composed of cellular Antoni $A$ areas $(X)$ and hypocellular Antoni $B$ areas (Y). B: Schwannoma consist of spindle cell in a loose myxoid or hyalinized stroma. C: Strong positivity for S-100 protein in a schwannoma. The tumor cells area strongly positive in their cytoplasm, while the nuclei are negative.

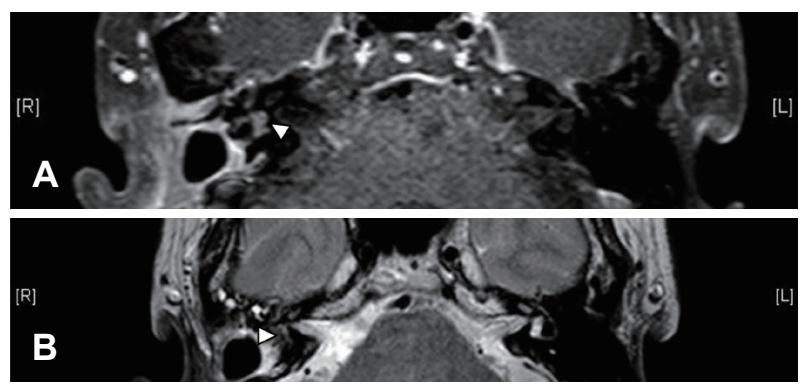

Fig. 6. Postoperative MRI temporal contrast. A: No sinal enhacement lesion in Rt. semicircular canal (MRI T1 Spectral Presaturation with Inversion Recovery Transverse Gadolinium). B: Heterogenous intensity in Rt. semicircular canal (MRI T2 Transverse).

\section{고 찰}

미로내 신경초종은 막성 미로(membranous labyrinth; $\mathrm{co}^{-}$ chlea, vestibule, or semicircular canals)에서 기원하는 종양 으로 정의한다. 이전에는 원발성 미로내 신경초종은 드문 것 으로 여겨졌으나 최근까지 130예 이상이 보고되었다. Salzman 등 ${ }^{11)}$ 에 따르면 미로내 신경초종 환자 45예 전부에서 청력 저 하를 호소하였으며 그중 27예는 점진적인 저하를, 14 예는 갑 작스러운 청력 저하를, 4 예에서는 변동이 있는 소견을 보였다.
Table 1. Classification of intralabyrinthine schwannoma

\begin{tabular}{ll}
\hline \multicolumn{1}{c}{ Class } & \multicolumn{1}{c}{ Area (s) of ear involved } \\
\hline Intravestibular & Vestibule \pm semicircular canals \\
Intracochlear & Cochlea \\
Intravestibulocochlear & Vestibule and Cochlea \\
Transmdiolar & Cochlea and IAC \\
Transmacular & Vestibule and IAC \\
\hline
\end{tabular}

IAC: internal auditory canal

두 번째로 흔한 증상으로는 이명이었는데 45예 중 23예에서 이명을 호소하였다.

국내에서 이전까지 문헌으로 보고 된 미로내 신경초종은 5 예 가 있었다. 본 증례까지 총 6예 중 4예는 청력 저하를 주소로 내원하였으며, 2예는 현훈을 주증상으로 내원하였다. 병변의 위치를 Kennedy 등 ${ }^{12}$ 의 분류(Table 1)에 따라 분류하였을 때 4예가 전정내 신경초종(intravestibular)이었고, 2예는 와우내 신경초종(intracochlear)이었다(Table 2). 다만 본 증례에서 조 금 다른 점은 전정에서 기원한 것으로 생각되는 종괴가 반규 관까지 침범하고 있었으며, 수술과정 중 반규관만을 개방하 여 대부분의 종괴를 제거하였다.

미로내 신경초종은 감각신경성 난청의 원인 중 드문 원인이 
Table 2. Brief description and classification of our case and previously reported cases in literature in Korea

\begin{tabular}{lcllll}
\hline \multicolumn{1}{c}{ Number } & Age & Sex & Chief complaints & \multicolumn{1}{c}{ Classification } & Treatment \\
\hline 1 (our case) & 55 & Female & Vertigo & Intravestibular & Translabyrinthine approach \\
2 Choi et al. ${ }^{10)}$ & 34 & Male & Vertigo & Intravestibular & Translabyrinthine approach \\
3 Choi et al. ${ }^{10)}$ & 50 & Female & Hearing impairment & Intravestibular & Translabyrinthine approach \\
4 Lee et al. ${ }^{13)}$ & 48 & Male & Hearing impairment & Intravestibular & Observation \\
5 Park et al. ${ }^{14)}$ & 48 & Male & Hearing impairment & Intracochlear & Modified transotic approach preserving EAC \\
6 Park et al. ${ }^{14)}$ & 27 & Male & Hearing impairment & Intracochlear & Observation \\
\hline
\end{tabular}

EAC: external auditory canal

나, 실제 유병률에 비해 더 적게 보고 된 원인이다. 또한 종양 의 성장이 매우 느리기 때문에 경도의 감각신경성 난청이 진 단된 후 수 년이 더 지나서야 진단되고는 한다. ${ }^{11}$

비대칭적인 청력의 저하는 신경초종을 진단하는데에 있어 가장 흔한 단서가 된다. 신경초종의 진단은 MRI의 수가 늘어 나며 진단되는 경우가 증가하고 있으며 CT보다 더 작은 크기 의 종양까지 진단할 수 있어 미로 내에만 존재하는 종양의 진 단도 증가하고 있다. 순수하게 미로 내에만 존재하는 신경초 종에서 청력의 저하 정도는 종양의 절대적인 부피의 증가율 과 관계가 있었다. 이런 점에서 종양이 청신경에 압력을 가해 청력저하가 생기는 것으로 보인다. ${ }^{15,16)}$

더 정교한 MRI의 발달과 함께 미로내 신경초종 진단의 민 감도는 높아졌다. 그러나, 미로내 신경초종이 매우 드문 경우 라는 이전까지의 보고는 이에 대한 영상의학과 의사의 인식 부족 때문이다. Salzman 등1ㅣㅇㅔ 따르면 최근 52 증례 중 미 로내 신경초종이 $10 \%$ 를 차지하고 있다.

신경초종(schwannoma) 진단에 있어 면역조직화학염색 (immunohistochemisty test)이 유용할 수 있는데 슈반세포 등에서 나타나는 S-100은 신경초종에서 강한 양성을 보인다. Calretinin은 중추신경계 및 말초신경계에서 표현되는 Calcium-binding protein으로 신경초종에서 양성 소견을 보인다. $\mathrm{CD}$ 56은 교세포(glia), 뉴런(neuron), 골격근(skeletal muscle) 의 표면에서 발현되는 당단백으로 신경초종에서 양성 소견이 나타난다. ${ }^{17)}$

미로내 신경초종의 치료는 종양의 위치나 증상, 그리고 양 상에 따라 다르다. 미로내 신경초종의 경우 청력을 보존하며 수술하는 것은 매우 어렵다. 따라서 보통의 경우 MRI로 추적 관찰하며 임상증상을 확인한다. 수술은 난치성 현훈이나 내 이도(internal auditory canal) 또는 중이까지 종양이 퍼질 경우 적응증이 된다. 미로내 신경초종 수술은 수술로 인해 영 향을 받는 귀의 경우 청력손실이 불가피하기에 수술을 결정 하는 것은 흔하지 않다. ${ }^{11)}$ 메니에르병(Menière's disase)에서 1형 전정유모세포(type I vestibular hair cell)에 비교적 선택 적으로 작용하여 조절되지 않는 현훈의 치료 선택지로 쓰이 는 고실내 젠타마이신 주입술(intratympanic gentamicin in- jection)도 58.3\%에서 현훈의 치료 효과를 볼 수 있다고 하며 미로내 신경초종에서 현훈의 치료에 사용될 수 있다고 한다. ${ }^{18)}$

본 환자의 경우 5 개월 전부터 난치성 현훈을 호소하였으며, 우측 고도 난청과 어음명료도 $0 \%$ 를 보인 환자로 경미로 접근 을 하더라도 청력에도 더 악영향을 주지 않으며, 전기안진 검 사 상 우측 반규관 마비 소견 보이는 환자로 추가적인 악화 가 능성은 높지 않아 수술로 인한 이점이 크다고 생각되었다. 또 한 추후 신경초종의 크기 증가로 인하여 안면마비 등의 증상 이 발생할 가능성이 있으며, 고실내 젠타마이신 주입술의 경 우에도 높은 효과를 보였으나 경유양동 미로내 절제술 같은 수술적인 처치의 경우 거의 $100 \%$ 에서 효과가 있었다는 ${ }^{19,20)}$ 이유로 환자분이 수술적인 처치를 선호하여 경유양동 미로절 제술을 시행하였다. 1990년 Jacobson과 Newman ${ }^{21}$ 이 어지 럼 환자를 대상으로 어지럼에 의한 일상생활 장애를 조사한 최초의 자기평가식 척도(selfassessment inventory)인 Dizziness Handicap Inventory 설문을 시행하였는데, 수술 전 환자 의 총 점수는 36 으로 높았던 것에 비해, 수술 후 6 개월 째 시 행한 설문에서는 총 점수 12 로 증상의 호전이 있었다. 본 환자 의 경우 수술 후 현훈에 관한 검사는 시행하지 않았으며 정기 적인 MRI로 신경초종의 재발을 감시하고 있다.

Kennedy 등 ${ }^{12)}$ 은 미로내 국한된 신경초종의 경우 $7 \%$ 에서 만 수술적인 처치가 필요하다고 기술하였으나, 국내 보고된 6예 중 4예에서 수술적인 처치를 시행하였다. 최근 영상검사 의 발달로 점차 미로내 신경초종의 진단이 늘어나고 있는 추 세를 고려하였을 때 국내에서도 앞으로 더 많은 증례가 보고 될 것으로 생각되며, 적절한 치료 가이드라인이 필요할 것으 로 생각한다.

\section{Acknowledgments}

None.

\section{Author Contribution}

Conceptualization: Hyunjong Jeon, Young Joon Seo. Data curation: Hyunjong Jeon, Heesung Chae. Formal analysis: Hyunjong Jeon. Funding acquisition: Hyunjong Jeon. Investigation: Hyunjong Jeon. Methodology: Hyunjong Jeon. Project administration: Hyunjong Jeon. Resources: Heesung Chae. Supervision: Young Joon Seo. Validation: Haneul Lee. Visualization: Haneul Lee. Writing — original draft: 
Hyunjong Jeon. Writing—review \& editing: Young Joon Seo.

\section{ORCIDs}

Young Joon Seo

Hyunjong Jeon

Heesung Chae

Haneul Lee

https://orcid.org/0000-0002-2839-4676

https://orcid.org/0000-0002-1345-236X

https://orcid.org/0000-0002-3629-8457

https://orcid.org/0000-0002-8893-1154

\section{REFERENCES}

1) Propp JM, McCarthy BJ, Davis FG, Preston-Martin S. Descriptive epidemiology of vestibular schwannomas. Neuro Oncol 2006;8(1): 1-11.

2) Stangerup SE, Tos M, Thomsen J, Caye-Thomasen P. True incidence of vestibular schwannoma? Neurosurgery 2010;67(5):1335-40.

3) Gruber B, Petchenik L, Williams M, Thomas C, Luken MG. Malignant vestibular schwannoma. Skull Base Surg 1994;4(4):22731.

4) Mayfield Brain \& Spine. Acoustic neuroma (vestibular schwannoma). [cited 2019 Jan 25]. Available from: URL: https://mayfieldclinic. com/pe-acoustic.htm.

5) Paldor I, Chen AS, Kaye AH. Growth rate of vestibular schwannoma. J Clin Neurosci 2016;32:1-8.

6) House WF, Hitselberger WE. Transtemporal bone microsurgical removal of acoustic neuromas. Total versus subtotal revmoval of acoustic tumors. Arch Otolaryngol 1964;80:751-2.

7) Huang X, Xu J, Xu M, Zhou LF, Zhang R, Lang L, et al. Clinical features of intracranial vestibular schwannomas. Oncol Lett 2013; 5(1):57-62.

8) Rutka J. Vestibular schwannomas or acoustic neuromas by another name. Canadian Audiologist 2014;1(4).

9) Karlan MS, Basek M, Potter GB. Intracochlear neurilemoma. Arch Otolaryngol 1972;96(6):573-5.
10) Choi JY, Son EJ, Choi HS, Kim KS. Two cases of intralabyrinthine schwannoma. Korean J Otorhinolaryngol-Head Neck Surg 2006; 49(4):434-8.

11) Salzman KL, Childs AM, Davidson HC, Kennedy RJ, Shelton C, Harnsberger HR. Intralabyrinthine schwannomas: Imaging diagnosis and classification. AJNR Am J Neuroradiol 2012;33(1): 104-9.

12) Kennedy RJ, Shelton C, Salzman KL, Davidson HC, Harnsberger HR. Intralabyrinthine schwannomas: Diagnosis, management, and a new classification system. Otol Neurotol 2004;25(2):160-7.

13) Lee SJ, Park SW, Auo HJ, Yoo YH. A case report of intravestibular schwannoma. Korean J Audiol 2007;11(2):143-146.

14) Park MW, Jang JH, Park MH. Two cases of intracochlear schwannoma. Korean J Otorhinolaryngol-Head Neck Surg 2009;52(12):996-1000.

15) Harner SG, Fabry DA, Beatty CW. Audiometric findings in patients with acoustic neuroma. Am J Otol 2000;21(3):405-11.

16) Caye-Thomasen P, Dethloff T, Hansen S, Stangerup SE, Thomsen J. Hearing in patients with intracanalicular vestibular schwannomas. Audiol Neurootol 2007;12(1):1-12.

17) Fine SW, McClain SA, Li M. Immunohistochemical staining for calretinin is useful for differentiating schwannomas from neurofibromas. Am J Clin Pathol 2004;122(4):552-9.

18) Covelli E, Volpini L, Filippi C, Tarantini S, Marrone V, Monini S, et al. Intralabyrinthine vestibular schwannoma responsive to intratympanic gentamicin treatment. J Int Adv Otol 2017;13(2):285-8.

19) Diaz RC, LaRouere MJ, Bojrab DI, Zappia JJ, Sargent EW, Shaia WT. Quality-of-life assessment of Ménière's disease patients after surgical labyrinthectomy. Otol Neurotol 2007;28(1):74-86.

20) Giannuzzi AL, Merkus P, Falcioni M. The use of intratympanic gentamicin in patients with vestibular schwannoma and disabling vertigo. Otol Neurotol 2013;34(6):1096-8.

21) Jacobson GP, Newman CW. The development of the dizziness handicap inventory. Arch Otolaryngol Head Neck Surg 1990;116(4): 424-7. 